\title{
ECOLOGICAL ASPECTS OF RIPARIAN FOREST REMNANTS IN THE SÃO JOÃO RIVER BASIN, PARANÁ
}

\author{
Juliana Gomes ${ }^{1}$, Adriane Ribeiro da Silva ${ }^{2}$, Bruna Pilati ${ }^{1}$, Anna Luiza Pereira Andrade ${ }^{3}$, Rosemeri de Oliveira \\ Fragoso $^{4}$, Marta Regina Barrotto do Carmo ${ }^{4 *}$
}

\author{
${ }^{1}$ State University of Ponta Grossa, Bachelor of Biological Sciences, Ponta Grossa, Paraná, Brazil - julianadutko@ @otmail.com, \\ bruna_pilati@hotmail.com \\ ${ }^{2}$ Federal University of Paraná, Graduate Program in Forest Engineering, Curitiba, Paraná, Brazil - drica.rivers@ gmail.com \\ ${ }^{3}$ University Center of Maringá, Ponta Grossa, Paraná, Brazil - annnaluiza@ yahoo.com.br \\ ${ }^{4}$ State University of Ponta Grossa, Department of General Biology, Ponta Grossa, Paraná, Brazil - meri_ol@ yahoo.com.br, \\ mrcarmo@uepg.br*
}

Received for publication: 16/09/2019 - Accepted for publication: 17/08/2020

\begin{abstract}
Resumo
As florestas ripárias são aquelas que acompanham os cursos d'água, formando corredores naturais de grande importância biológica para o ambiente em que estão inseridas. Assim, tendo em vista a relevância dessas áreas, o presente trabalho objetivou levantar informações sobre os remanescentes de floresta ripária localizados na Bacia do Rio São João, Paraná, como forma de subsidiar o diagnóstico ecológico da vegetação e permitir a definição de ações de conservação e restauração da área, bem como sua utilização em futuros planos de manejo. Para o estudo foram amostradas espécies lenhosas dos estratos superior (PAP $\geq 15 \mathrm{~cm}$ ) e inferior $(\mathrm{PAP}<15 \mathrm{~cm}$ e altura $\geq 2 \mathrm{~m}$ ), por meio do método de quadrantes, em oito estações de coleta ao longo do rio São João. Com base no levantamento florístico e parâmetros fitossociológicos observados foi possível verificar que os remanescentes de floresta ripária se encontram bastante degradados, apresentando predominantemente plantas típicas de estágios iniciais da sucessão, resultado de ações antrópicas em seu entorno. Por outro lado, a análise dos atributos reprodutivos revelou a existência de espécies em floração e frutificação durante o ano todo, bem como de elevado número de plantas zoófilas e zoocóricas, atributos essenciais para a manutenção dos processos ecológicos e garantia de manutenção dos serviços ecossistêmicos. Avigora-se a necessidade de ações de conservação e restauração dessa área, para reduzir os efeitos da fragmentação da paisagem, provendo suporte adequado ao desenvolvimento da comunidade.
\end{abstract}

Palavras-chave: comunidade arbórea, floração, frutificação, grupos funcionais, Floresta Ombrófila Mista Aluvial.

\begin{abstract}
Riparian forests are those that accompany waterways, forming natural corridors with great biological importance in the environments in which they are inserted. Thus, due to the relevance of these areas, this study aimed to increase information about riparian forest remnants located in the São João River basin, Paraná, to subsidize the ecological diagnosis of vegetation and to determine conservation and restoration actions for the area, as well as for its use in future management plans. In this study, woody species in the upper $(\mathrm{CBH} \geq 15 \mathrm{~cm})$ and lower $(\mathrm{CBH}<15 \mathrm{~cm}$ and height $\geq 2 \mathrm{~m})$ strata were sampled using the quadrants method from eight collection stations along the São João River. Based on the floristic survey and phytosociological parameters observed, it was possible to verify that the riparian forest remnants are quite degraded, presenting a majority of plants that are common in early stages of succession, due to surrounding anthropic actions. On the other hand, the analysis of reproductive attributes revealed the existence of flowering and fruiting species throughout the year, as well as a high number of zoophilic and zoochoric plants, attributes essential for maintaining ecological processes and ensuring ecosystem services. Conservation and restoration actions are needed in this area to reduce the effects of landscape fragmentation, in order to provide adequate support for community development.

Keywords: arboreal community, flowering, fruiting, functional groups, mixed ombrophilous alluvial forest.
\end{abstract}

\section{INTRODUCTION}

In the river basins, riparian forests are considered priority areas for preservation as they are needed to maintain terrestrial and aquatic ecosystems, which permits the management of entire landscapes (TAMBOSI $e t$ al., 2015). These forests help form natural corridors that reduce the effects of forest fragmentation, enable gene flow and increase genetic variability of species (FREMIER et al., 2015). For this reason, the importance of riparian forests in protecting watercourses and their assignment as permanent preservation areas (PPA), according to the Brazilian Forestry Code, is widely recognized in the literature (REMPEL et al., 2018).

FLORESTA, Curitiba, PR, v. 51, n. 2, p. 391-399, abril/jun 2021.

Gomes, J. et.al.

ISSN eletrônico 1982-4688 
Despite their relevance, anthropic actions have greatly impacted riparian forests, with only a few fragments remaining. In Brazil, the main activities responsible for degradation of these areas are agricultural and livestock enterprises, and their continuous expansion to increase production (VOGEL et al., 2009). Thus, integrated management of riverside areas is necessary and results in resource optimization in restoration projects of degraded ecosystems.

In this sense, ecological studies in river basins are fundamental for understanding natural resource use and environmental impact prevention, and to ensure ecosystem services (CLERICI et al., 2014). Floristic and phytosociological studies provide a basis of knowledge about plant communities and their relationships, as well as their distribution in an environment (POTT, 2011). Similarly, recognizing functional groups of plant species helps to recognize the development of ecological processes. Characteristics such as reproductive periods and dispersal and pollination syndromes of plants are directly related to forest succession and maintenance, and animalplant interactions are fundamental in conserving biodiversity (BELLO et al., 2010).

Considering the aspects mentioned, the proper management of riparian forests and success of restoration actions should be based on restoring ecological processes in the ecosystem. Thus, the present study aimed to sample two arboreal vegetation strata and provide information about reproductive and ecological attributes of small riparian forest remnants located in the São João River basin, Paraná state. Such diagnosis of vegetation will define appropriate strategies for the conservation of such areas, as well as the restoration and management actions needed to maintain ecosystem services.

\section{MATERIALS AND METHODS}

\section{Study Area}

The São João River basin (SJRB), which belongs to the Tibagi River basin, has a total area of about 143 $\mathrm{km}^{2}$ and is located in the Carambeí municipality, with a small northeast portion located in the Castro municipality (Paraná state). Altitude ranges from $812 \mathrm{~m}$ to $1205 \mathrm{~m}$ (GUIMARÃES et al., 2014). The climate is classified by Köppen as $\mathrm{Cfb}$ (Humid Temperate), with the hottest average month less than $22{ }^{\circ} \mathrm{C}$ and the coldest average month below $18{ }^{\circ} \mathrm{C}$, without a defined dry season and with severe and frequent frost. Average annual rainfall is between $1400 \mathrm{~mm}$ to $1600 \mathrm{~mm}$, presenting rainy summers and drier winters, as seen in subtropical or temperate regions. The soil along the river in almost completely made up of Lithic-humic Leptosols (GUIMARÃES et al., 2014).

SJRB lies within a region known as Campos Gerais, which predominantly presents natural fields, with occasional Cerrado relicts and mixed ombrophilous forest areas in the form of forest islands and accompanying the river courses. Currently, the occupation and land use of SJRB is mainly rural, with emphasis on agriculture and livestock, as well as the reforestation of exotic species as Eucalyptus spp. and Pinus elliottii. It also contains industrial facilities and catchment point of the Paraná Sanitiation Company (Sanepar) for water supply of the Carambeí municipality, which represents approximately $54 \%$ of the average monthly water production for this municipality.

\section{Data gathering}

In this study, eight collection stations were selected (Figure 1) that present some preserved strips of forest vegetation along the São João River. Using the quadrant methodology, 25 points were assigned in each collection station, (equidistant at $10 \mathrm{~m}$ ) and needed to include two individuals (tree) per quadrant (totaling eight individuals per point): one with a circumference at breast height $(\mathrm{CBH})$ equal to or greater than $15 \mathrm{~cm}$ to sample the Upper Stratum (US); the other with $\mathrm{CBH}$ less than $15 \mathrm{~cm}$, but greater than or equal to $2 \mathrm{~m}$ to sample the Lower Stratum (LS). For each individual sampled, the height, $\mathrm{CBH}$, distance between the point and the nearest individual, and the species name were recorded. When it was not possible to identify the species at the collection station, botanical samples were collected, which were subsequently herborized and incorporated into the Herbarium of the State University of Ponta Grossa (HUPG).

FLORESTA, Curitiba, PR, v. 51, n. 2, p. 391-399, abril/jun 2021.

Gomes, J. et.al. 

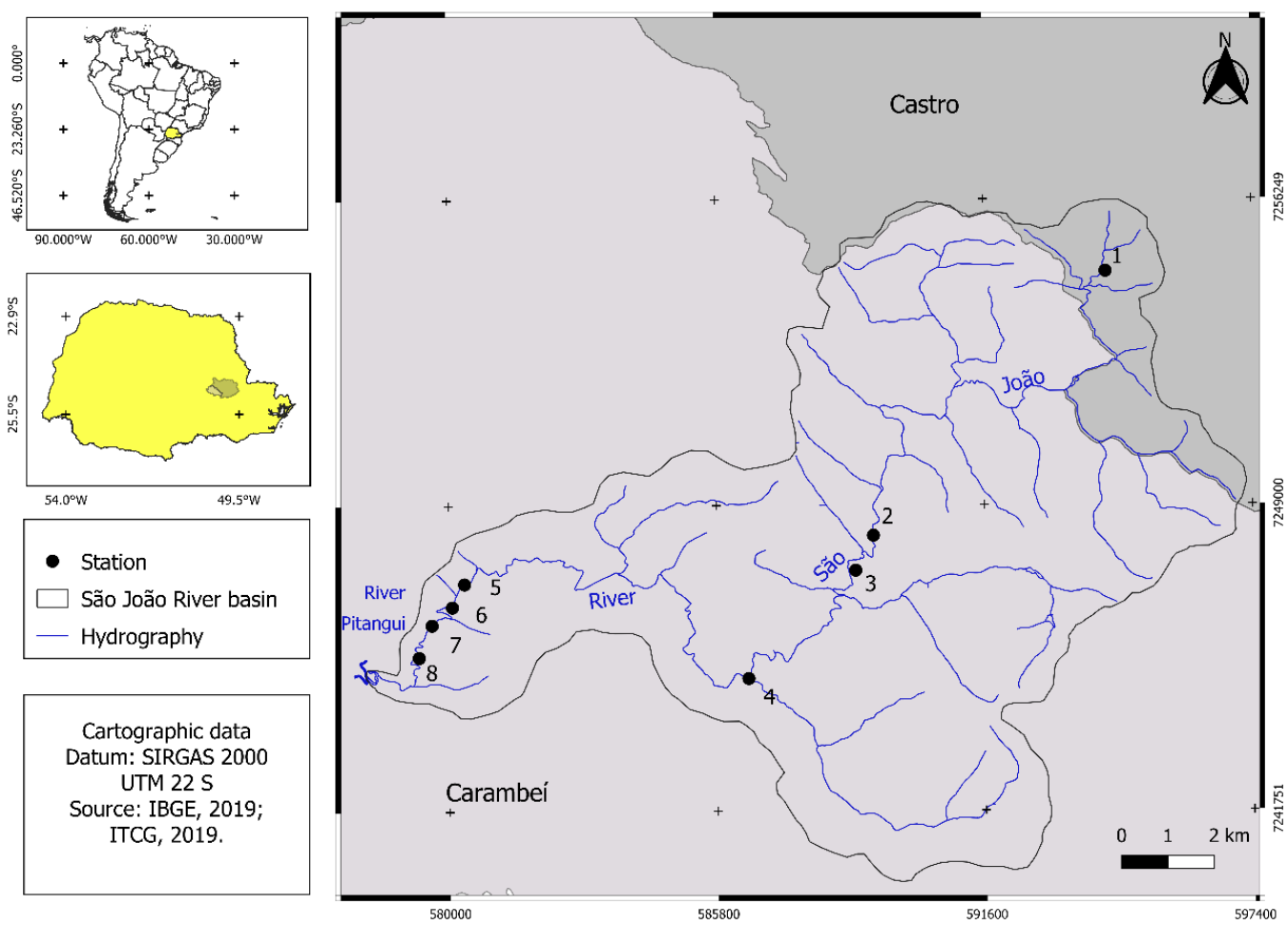

Figure 1. Location of the São João River basin in Paraná state and data collection stations in the Riparian forest remnants along the São João River, Carambeí, PR.

Figura 1. Localização da Bacia do Rio São João no estado do Paraná e estações de coleta de dados em remanescentes da floresta ripária. ao longo do rio São João, Carambeí, PR.

Species determination was performed using specific bibliographies, comparisons with specimens listed in HUPG, and consultations with specialists. Names of the taxa followed the APG IV (2016) classification system.

To obtain phenological data, surveys were carried out in the literature and in the database about flowering and fruiting seasons of the species sampled in the study, based on information from forests in southern Brazil. The species were classified as zoochoric, anemochoric, or autochoric for dispersal syndromes (PIJL, 1982) and as zoophilic or anemophilic for pollination syndromes (FAEGRI; PIJL, 1976). In zoophily, plants pollinated by insects (bees, flies, moths, butterflies and other small insects), bats and birds were included. Subsequently, species were separated by their successional categories into pioneer, early secondary, late secondary and climactic.

\section{Data analysis}

To verify the sample sufficiency, we compared the richness observed to the estimated richness in the entire sampling and for the US and LS using a Bootstrap estimator. The richness data was randomized 100 times to avoid influence of the order of input of each data point and calculations were performed in the EstimateS 8.2.0 program.

The phytosociological parameters of relative density, relative frequency, relative dominance and the importance value (IV) were calculated using the Fitopac software. To evaluate the floristic similarities between the collection stations and the sampled strata, a cluster analysis (UPGMA) was performed using the Jaccard similarity index to measure similarity. Shannon $\left(\mathrm{H}^{\prime}\right)$ and Equability $\left(\mathrm{J}^{\prime}\right)$ diversity indices were also calculated for the strata at different collection stations. All calculations and the Dendrogram were performed in the Past 3.0 program.

\section{RESULTS}

127 species were sampled, distributed in 40 families. However, nine angiosperm species have not been identified yet. For the US, 90 species and 37 families were found, while for the LS, 103 species and 34 families were found. We sampled 44 individuals that died standing, 31 in US and 13 in LS.

The richness estimated by Bootstrap accounted for $86.76 \%$ (147.54 species) in the entire survey, $84.93 \%$ (107.14) for the US and $85.55 \%$ (121.57) for the LS, reflecting a satisfactory sampling (Figure 2).

FLORESTA, Curitiba, PR, v. 51, n. 2, p. 391-399, abril/jun 2021.

Gomes, J. et.al.

ISSN eletrônico 1982-4688 


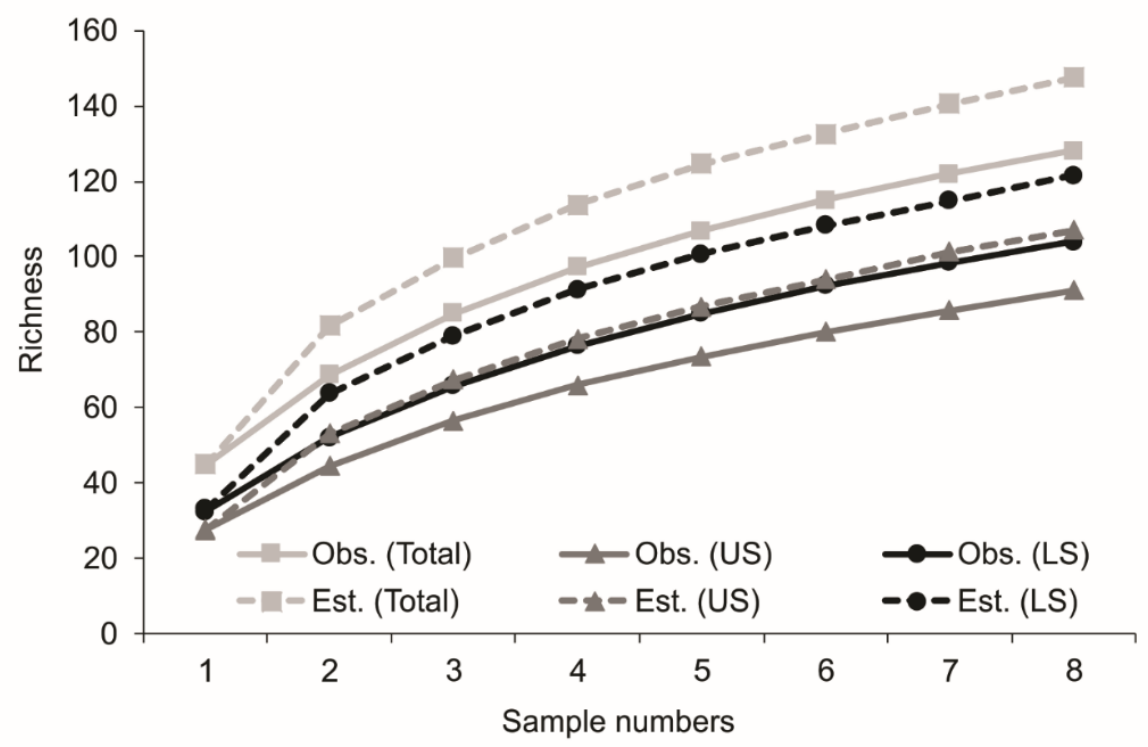

Figure 2. Species richness observed (Obs.) and estimated (Est.) by Bootstrap for total sampling and for the Upper (US) and Lower (LS) strata in the riparian forest remnants in the São João River basin, Carambeí, Paraná.

Figura 2. Riqueza de espécies observada (Obs.) e estimada (Est.) pelo Bootstrap para a amostragem total e para os estratos superior (US) e inferior (LS), nos remanescentes de floresta ripária da bacia do rio São João, Carambeí, Paraná.

The families that most contributed to richness and abundance in both strata were Myrtaceae, Lauraceae and Euphorbiaceae. These families presented 31\% and 34\% of the total species, and 33\% and 39\% of the total number of individuals sampled in the US and LS, respectively.

The species with the highest importance value (IV) for the US were Anadenanthera colubrina (50.41), Gymnanthes klotzschiana (44.43), Matayba elaeagnoides (15.68), dead class (12.12), Nectandra grandiflora (10.40), Lafoensia pacari (9.66), Calyptranthes concinna (7.81), Jacaranda puberula (7.06), Araucaria angustifolia (6.78) and Clethra scabra (6.77). Together they accounted for $57.04 \%$ of the total IV and $55.51 \%$ of the individuals sampled in this stratum. The species that presented only one individual and IV less than 1.00 comprised $31.11 \%$ of the species.

For the LS, the species with the highest IV were Gymnanthes klotzschiana (29.71), Casearia sylvestris (24.30), Matayba elaeagnoides (17.24), Myrsine umbellata (17.12), Myrcia multiflora (11.98), Prunus brasiliensis (11.91), Anadenanthera colubrina (8.40), Myrcia obtecta (8.04), Calyptranthes concinna (7.83) and Nectandra grandiflora (5.62). These 10 species made up $47.38 \%$ of the total IV and $47.26 \%$ of the individuals sampled in the LS. Species that presented only one individual and IV less than 1.0 represented $35.92 \%$ of the species.

The diversity of the arboreal community is represented by a Shannon $\left(\mathrm{H}^{\prime}\right)$ index of 3.5 for the US and 3.9 for the LS. The Equability values $\left(\mathrm{J}^{\prime}\right)$ for the US and the LS were 0.78 and 0.84 , respectively, which helps increase the diversity index value and expresses the absence of ecological dominance of species. The Shannon analysis values in each collection station in the US and the LS reveal a tendency of reduced species diversity in stations 1 and 2, which are considered more preserved, and in stations 7 and 8, which are considered more degraded (Table 2). According to the Jaccard index, the floristic similarity of the strata was $52 \%$, presenting 67 species in common. Similarity indices (Jaccard) between $25 \%$ and $40 \%$ (Table 2) were found among the collection stations in each stratum.

The dendrogram analysis (Figure 3) indicates the formation of two groups, according to the degree of disturbance of the area. The first group consisted of stations 1,2 and 3, which in addition to proximity, presented better preservation conditions, with the presence of Araucaria angustifolia, threatened with extinction. The second group was formed by stations $4,5,6,7$ and 8 , which are quite altered, formed by sparse vegetation, consisting mainly of Gymnanthes klotzschiana and Anadenanthera colubrina, as well as the striking presence of Eucaliptus sp. and Pinus sp in its surroundings.

FLORESTA, Curitiba, PR, v. 51, n. 2, p. 391-399, abril/jun 2021.

Gomes, J. et.al.

ISSN eletrônico 1982-4688 
Table 2. Relation of the number of species and Shannon diversity and Jaccard similarity indices by collection station, in the upper (US) and lower (LS) strata along the São João River basin, Carambeí, Paraná.

Tabela 2. Relação do número de espécies e índices de diversidade de Shannon e de similaridade de Jaccard por estação de coleta, nos estratos superior (US) e inferior (LS) ao longo da bacia do Rio São João, Carambeí, Paraná.

\begin{tabular}{cccccccc}
\hline \multirow{2}{*}{ Station } & \multicolumn{9}{c}{ Species } & \multicolumn{5}{c}{ Shannon } & \multirow{2}{*}{ Jaccard } & US x LS \\
\cline { 2 - 6 } & Total & US & LS & Total & US & LS & 0,36 \\
& 61 & 35 & 48 & 3,70 & 3,16 & 3,61 & 0,40 \\
2 & 53 & 36 & 38 & 3,58 & 3,23 & 3,29 & 0,28 \\
3 & 58 & 38 & 36 & 3,66 & 3,30 & 3,30 & 0,38 \\
4 & 42 & 30 & 28 & 3,02 & 2,85 & 2,60 & 0,39 \\
5 & 36 & 21 & 29 & 2,90 & 2,33 & 2,99 & 0,30 \\
6 & 40 & 25 & 27 & 3,11 & 2,62 & 2,98 & 0,39 \\
7 & 36 & 22 & 28 & 2,93 & 2,57 & 2,87 & 0,25 \\
8 & 32 & 14 & 26 & 2,60 & 1,91 & 2,78 & \\
\hline
\end{tabular}

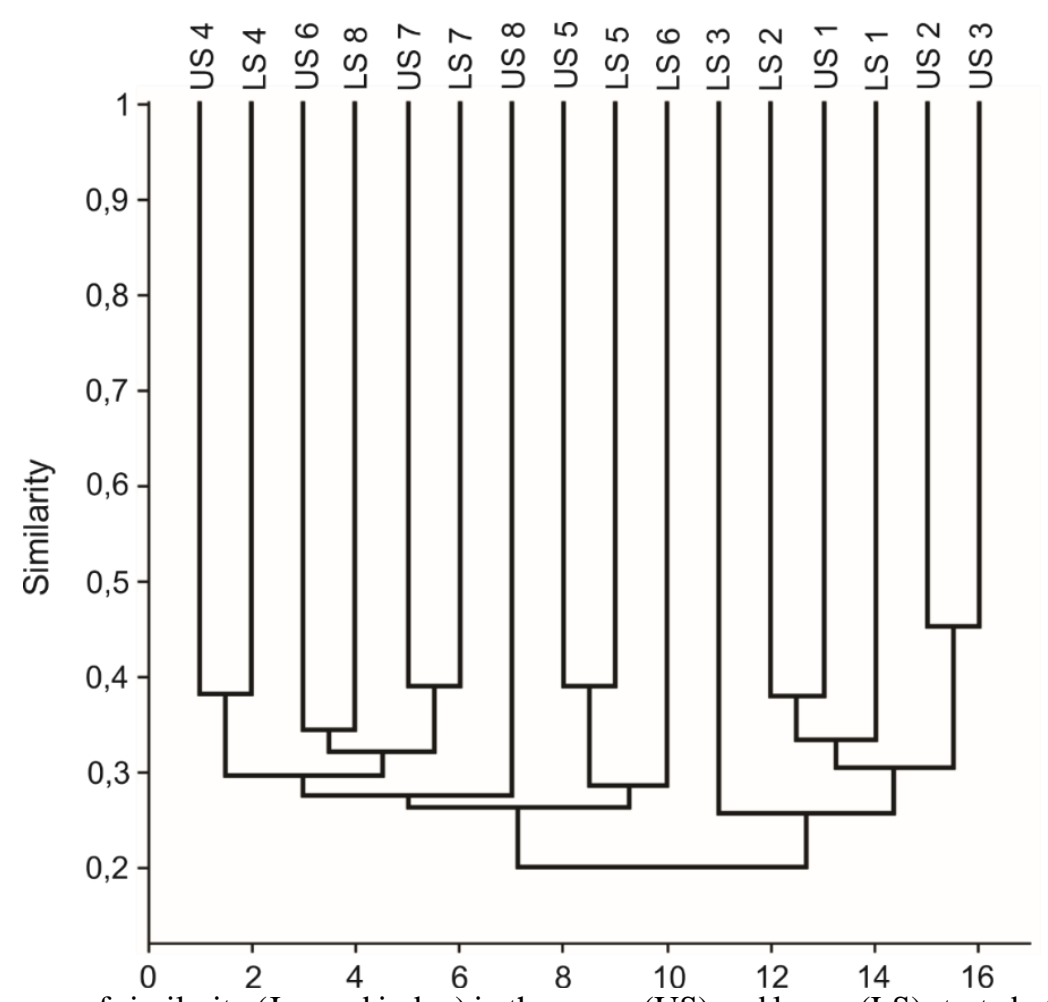

Figure 3. A dendrogram of similarity (Jaccard index) in the upper (US) and lower (LS) strata between the collection stations in the riparian forest remnants of the São João River basin, Carambeí, Paraná.

Figura 3. Dendrograma de similaridade (índice de Jaccard) nos estratos superior e inferior entre as estações de coleta nos remanescentes de floresta ripária da bacia do rio São João, Carambeí, Paraná.

Both strata of the riparian forest presented flowering peaks from August to November, months of transition from dry to wet seasons, and fruiting peaks from December to January, months with higher precipitation rates. On the other hand, the lowest incidences of flowering and fruiting occurred in the months of June and July, during which precipitation records were low (Figures 4A and 4B).

Zoochory predominated as the dispersal syndrome of the species, with percentages of $72 \%$ in US and $80 \%$ in LS, followed by anemochory with $16 \%$ and $12 \%$ for US and LS, respectively. Autochoric species totaled 
$12 \%$ for US and $8 \%$ for LS. Zoochoric species were those that presented greatest fruiting periods throughout the whole year in the two strata studied, with a slight decrease from May to August. In this period, anemochoric and autochoric species had higher representativeness (Figures 4C and 4D). Zoophily was the dominant syndrome and verified in $96 \%$ of the plants in both strata.
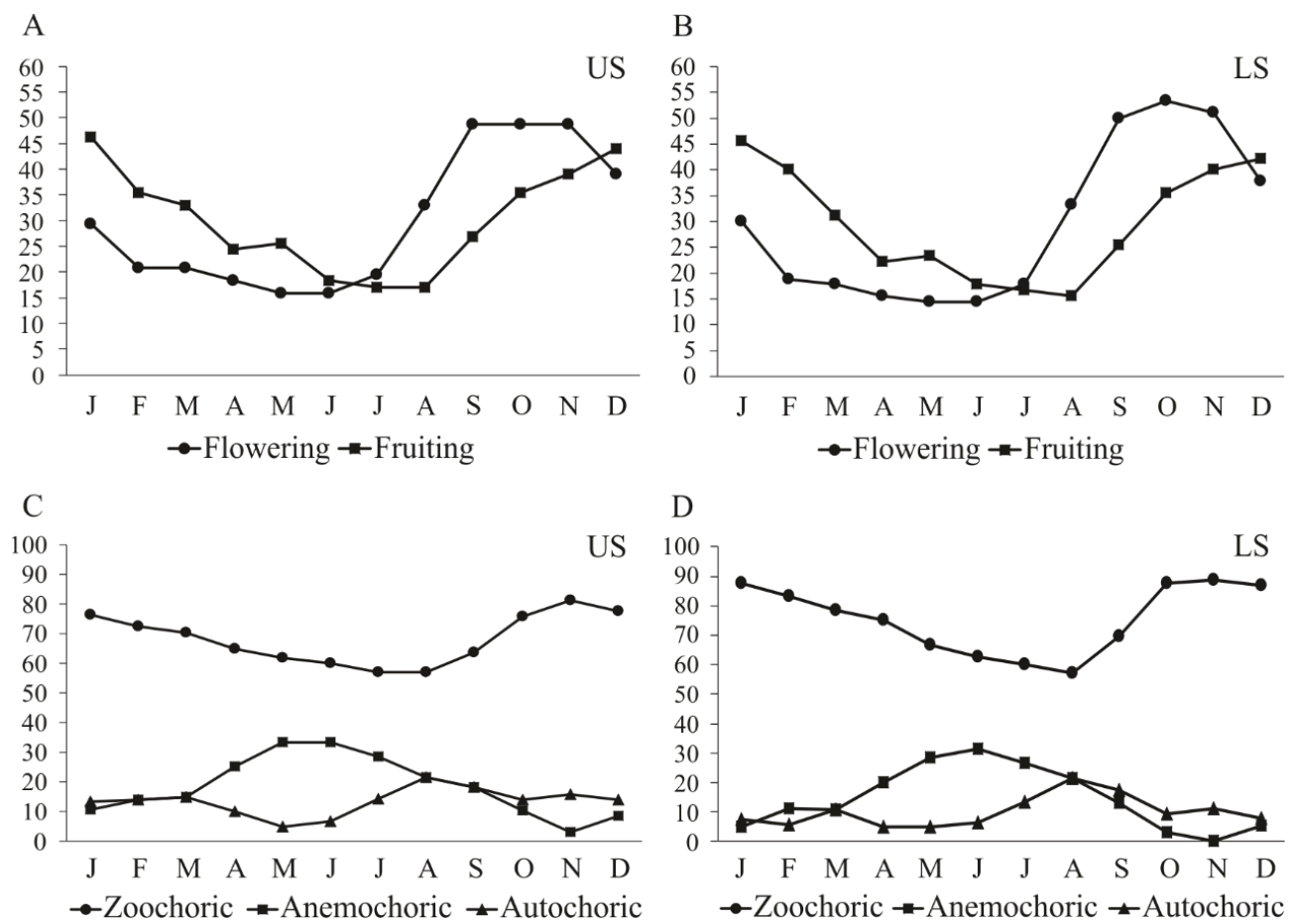

Figure 4. Percentage of total species flowering and fruiting (A and B) and fruiting species by dispersal syndrome (C and D) throughout the year in the upper (US) and lower (LS) strata in the riparian forest remnants of the São João River basin, Carambeí, Paraná.

Figura 4. Percentual de espécies totais em floração e frutificação (A, B) e de espécies em frutificação por síndrome de dispersão (C e D) ao longo do ano nos estratos superior (LS) e inferior (LS) nos remanescentes de floresta ripária da bacia do rio São João, Carambeí, Paraná.

The ciliary forests of the São João River basin predominantly presented plants of early stages of succession, reaching percentages of $19 \%$ and $28 \%$ for pioneer species and $43 \%$ and $33 \%$ for initial secondary in US and LS, respectively. Nevertheless, species of the later categories of succession are also present, reaching percentages of $29 \%$ and $9 \%$ for late secondary and $30 \%$ and $9 \%$ for climactic in the upper and lower strata, respectively.

\section{DISCUSSION}

Although the riparian forests of SJRB appear as narrow strips, interrupted by deforestation and exotic species that have developed at their borders, they are still characterized by the distinct presence of Myrtaceae, Lauraceae and Euphorbiaceae species, typical to mixed ombrophilous alluvial forest formations (CARMO; ASSIS, 2012; REMPEL et al., 2018).

In addition, the number of species found in the US is considered high when compared to results obtained in other studies carried out in riparian forest remnants (NASCIMENTO et al., 2011; STEDILLE et al., 2018). The highest species richness is also verified in the LS, even though studies about understory plant communities are scarcer (BARDDAL et al., 2004). Species richness is related to the high or low environmental heterogeneity present in these sites (SARAIVA, 2011), that is largely dictated by soil hydromorphy, which imposes a certain degree of selectivity on species adapted to these conditions (CARVALHO et al., 2009). Araucaria angustifolia, for example, tends to disappear in riverside environments, being restricted to areas with better soil drainage, while "branquilho" (Gymnanthes klotzschiana), a species that stood out in both strata, is common in hydromorphic soils and can become dominant in such environments (FREITAS et al., 2017).

FLORESTA, Curitiba, PR, v. 51, n. 2, p. 391-399, abril/jun 2021

Gomes, J. et.al.

ISSN eletrônico 1982-4688 
The species listed in this study are widely recognized as occurring in ciliary forests (FLOSS et al., 2018), especially in the Campos Gerais region of Paraná (CARMO; ASSIS, 2012), and are considered essential for the forest structure and ecological restoration projects in the area (SILVA et al., 2013). Besides branquilho, a species that was found in all collection stations, "angico" (Anadenanthera colubrina) also stood out in the area, especially in the US. This species has been recommended for recovery due to its adaptability to shallow and low chemical fertility soils, as well as to flooded lands (MARTINEZ et al., 2013). The inclusion of nitrogen-fixing legumes is a recurrent practice in degraded ecosystem restoration programs and is considered an efficient strategy for local soil improvement, consequently facilitating succession (CHAER et al., 2011).

The diversity values from the arboreal community of SJRB were higher than those commonly reported in other studies about this forest typology (GONÇALVES et al., 2018; STEDILLE et al., 2018). However, these values approach those found in forest areas that occur along water courses (NASCIMENTO et al., 2011), confirming the high floristic heterogeneity in the area due to considerable environmental variation.

The strata showed floristic similarity, indicating that recruitment of individuals present in the US has occurred through seed rain and seed bank; however, the higher diversity found in the LS suggests that, although propagules of other species are reaching the area, there are environmental constraints that cause less species to be recruited in the US. For example, the tolerance to soil water saturation is cited (CARVALHO et al., 2009), which would also justify the high occurrence of dead plants observed in the US. On the other hand, the small similarity observed among collection stations reflects the different levels of degradation present along the São João River basin, which results from the strong fragmentation of remnants, and contributes to the high environmental heterogeneity present in the area. These results are consistent because many areas are not connected to any neighboring forest fragments, which favors species with more efficient dispersal mechanisms and may represent a reduction in biological integrity of the remnants and its role as an ecological corridor.

Although the riparian forest studied is composed of species with year-round flowering and fruiting records, guaranteeing attractive food resources for fauna, in both strata flowering and fruiting peaks occur in months with increased precipitation, temperature and photoperiod rates. Conversely, fruiting of the anemochoric species in the driest months of the year (including higher wind incidence) is related to favorable environmental conditions for seeds with wind dispersal mechanisms. This pattern has already been described in woody riparian vegetation (CARMO; MORELLATO, 2000), since periods of higher flowering and fruiting are dictated by zoophilic and zoochoric species, related to increased visitation of pollinators and dispersers. This is an important aspect for the successional dynamics and increased environmental richness in secondary succession, which is also described for tropical and subtropical forests (CARMO; MORELLATO, 2000; RODRIGUES et al., 2010; BEAUNE et al., 2013). Thus, the high number of plants that present attractive elements for animals in the São João River basin contributes to better species distribution, since percentages of pollination and dispersion through other mechanisms are low.

The favoring of initial succession species in riparian vegetation was expected, being commonly due to the marked presence of light in these fragments surrounded by non-forest matrices such as monocultures and pastures. On the other hand, the lower proportion of plants from later stages of succession indicates that these species have encountered difficulties in recruiting individuals in the arboreal stratum. In addition to the anthropic action, an important factor is the flood pulses, which are frequent in these environments and act as an environmental filter, favoring the establishment of fast-growing and flood tolerant species, as well as species with greater phenotypic plasticity (SARAIVA, 2011), as is the case of Gymnanthes klotzschiana, which was highlighted in this study. Early pioneer and secondary species have high ecological value in the community, as they develop in disturbed environments, produce many seeds dispersed by generalist agents and form a viable seed bank for a long period. Nevertheless, important species of later successional stages are also present, such as Matayba elaeagnoides, Nectandra grandiflora and Calyptranthes concinna.

Although the richness of native arboreal species found in SJRB is comparable to other forests, vegetation was largely destroyed, and this study only recorded specimens from what originally existed surviving. Thus, in order to recover the riparian vegetation, actions to protect the area and permanent cessation of disturbances are recommended, respecting forest legislation that establishes the forest boundaries according to the riverbed width. These measures aim to avoid the entry of people, sand and plant extraction activities, fires and emission of untreated domestic and agroindustrial effluents (GEALH; MELO, 2014), promoting natural regeneration and maintaining water quality. Furthermore, such actions control the advancement of highly inhibiting or invasive exotic species (the case of Pinus spp.), aiming at their local eradication.

It should be noted that in very degraded areas, with low native vegetation cover, the recovery of natural regeneration is slow or non-existent, requiring species to be introduced through restoration actions. For planting,

FLORESTA, Curitiba, PR, v. 51, n. 2, p. 391-399, abril/jun 2021.

Gomes, J. et.al.

ISSN eletrônico 1982-4688 
priority should be given to the species present in the floristic survey, which are important in riparian environments of mixed ombrophilous forests, and that present few individuals, such as Allophylus edulis, Casearia decandra, Syagrus romanzoffiana, Luehea divaricata, Actinostemon concolor, Campomanesia xanthocarpa, Ficus guaranitica and Ocotea porosa, belonging to the initial and late stages of succession. Among these, nucleator species should be prioritized, as they are able to produce fruits during many months of the year (i.e., fig trees) or in times that few other species fruit (i.e., Syagrus romanzoffiana).

\section{CONCLUSIONS}

Based on the floristic survey and phytosociological parameters observed in the vegetation bordering the watercourses in the São João River basin, it is possible to conclude that:

- The remnants of riparian forest are quite degraded, with reduced floristic similarity between them and species of early stages of succession dominating.

- The presence of flowering and fruiting species throughout the year, as well as the high number of zoophilic and zoochoric plants, are important attributes that maintain ecological processes, since several species play the same functional role and guarantee a particular function.

- It is recommended to increase the connectivity of the landscape through conservation and restoration actions, in order to reduce the chances of local extinctions and minimize restrictions on the colonization of new species and ecological groups in the future, providing adequate support for community development.

\section{ACKNOWLEDGMENTS}

We thank to Araucaria Foundation for the undergraduate scholarship to A.R. da Silva and B. Pilates, and municipal administration of Carambeí for the part financial support.

\section{REFERENCES}

APG IV. An update of the Angiosperm Phylogeny Group classification for the orders and families of flowering plants: APG III. Botanical Journal of the Linnean Society, London, v. 181, n. 1, p. 1-20, 2016.

BEAUNE, D.; BRETAGNOLle, F.; BOLlaChE, L.; HOHMANN, G.; SURBECK, M.; FRUTH, B. Seed dispersal strategies and the threat of defaunation in a Congo forest. Biodiversity and Conservation, New York, v. 22 , n. 1, p. 225-238, 2013.

BELLO, F.; LAVOREL, S.; DÍAZ, S.; HARRINGTON, R.; CORNELISSEN, J. H. C.; BARDGETT, R. D.; BERG, M. P.; CIPRIOTTI, P.; FELD, C. K.; HERING, D.; SILVA, P. M.; POTTS S. G.; SANDIN, L.; SOUSA, J. P.; STORKEY, J.; WARDLE, D. A.; HARRISON, P. A. Towards an assessment of multiple ecosystem processes and services via functional traits. Biodiversity and Conservation, New York,v. 19, n. 10, p. 2873-2893, 2010.

CARMO, M. R. B.; MORELlATO, L. P. C. Fenologia de árvores e arbustos das matas ciliares da Bacia do rio Tibagi, Estado do Paraná, Brasil. In: RODRIGUES; R. R. LEITÃO FILHO, H. F. Matas Ciliares: conservação e recuperação. São Paulo: Edusp, Fapesp, 2000. p. 125-141.

CARMO, M. R. B.; ASSIS, M. A. Caracterização florística e estrutural das florestas naturalmente fragmentadas no Parque Estadual do Guartelá, município de Tibagi, estado do Paraná. Acta Botanica Brasilica, Feira de Santana, v. 26, n. 1, p. 133-145, 2012.

CARVALHO, J.; MARQUES, M. C. M.; RODERJAN, C. V.; BARDDAL, M.; SOUSA, S. G. A. Relações entre a distribuição das espécies de diferentes estratos e as características do solo de uma floresta aluvial no Estado do Paraná, Brasil. Acta Botanica Brasilica. São Paulo, v. 23, n. 1, p. 1-9, 2009.

CHAER, G. M.; RESENDE, A. S.; CAMPELLO, E. F. C.; FARIA, S. M.; BODDEY, R. M. Nitrogen-fixing legume tree species for the reclamation of severely degraded lands in Brazil. Tree Physiology, Oxford, v. 31, n. 2, p. 139-149, 2011.

CLERICI, N.; PARACCHINI, M. L.; MAES, J. Land-cover change dynamics and insights into ecosystem services in European stream riparian zones. Ecohydrology \& Hydrobiology, Lódz, v. 14, n. 2, p. 107-120, 2014.

FAEGRI, K.; PIJL, L. The principles of pollination ecology. Pergamon Press, 1976. 291p.

FLORESTA, Curitiba, PR, v. 51, n. 2, p. 391-399, abril/jun 2021.

Gomes, J. et.al. 
FLOSS, P. A.; LONGHI, S. J.; COSTA, M. D. P.; FLOSS, E. C. S. Environmental structure and relationships in the setting of natural water springs in a Lower Highland Seasonal Forest in Brazilian South. Ciência Rural, Santa Maria, v. 48, n. 11, e20170857, 2018.

FREITAS, W. K.; MAGALHAES, L. M. S.; VIVES, L. R. Floristic, diversity and spatial distribution of tree species in a dry forest in Southern Brazil. Applied Ecology and Environmental Research, Budapest, v. 15, n. 1, p. 511-524, 2017.

FREMIER, A. K.; KIPARSKY, M.; GMUR, S.; AYCRIGG, J.; CRAIG, R. K.; SVANCARA, L. K.; GOBLE, D. D.; COSENS, B.; DAVIS, F.; SCOTT, J. M. A riparian conservation network for ecological resilience. Biological Conservation, v. 191, p. 29-37, 2015.

GONÇALVES, D. A.; SILVA, A. C. D.; HIGUCHI, P.; GROSS, A.; RODRIGUES JUNIOR, L. C.; WALTER, F. F.; LOEBENS, R.; MISSIO, F. F.; PSCHEIDT, F.; FERREIRA, T. S.; RECH, C. C. C.; ROSA, A. D.; JUNIOR, F. B.; BENTO, M. A.; CRUZ, A. P. Heterogeneity of a tree species community in an alluvial area of Santa Catarina, Brazil. Floresta e Ambiente, Seropédica, v. 25, n. 2, 2018.

GUIMARÃES, G. B.; GODOY, L. C.; MELO, M. S.; FLÜGEL FILHO, J. C. Geodiversidade. In: GEALH A. M., MELO M. S. Rio São João, Carambeí, PR: fonte de vida, cuidados devidos. Ponta Grossa: Ed. UEPG, 2014. p. 17-37.

MARTINEZ, O. G.; BARRANDEGUY, M. E.; GARCÍA, M. V.; CACHARANI, D. A.; PRADO, D. E. Presencia de Anadenanthera colubrina var. colubrina (Fabaceae, Mimosoideae) en Argentina. Darwiniana, Córdoba, v. 1, n. 2, p. 279-288, 2013.

NASCIMENTO, A. R. T.; RAMOS, P. H. X.; DALMASO, C. A. Estrutura e classificação de um remanescente de floresta ripária no município de Lages, SC. Ciência Florestal, Santa Maria, v. 21, n. 2, p. 209-218, 2011.

PIJL, L. Principles of dispersal in higher plants. Springer-Verlag, 1982. 218p.

POTT, R. Phytosociology: A modern geobotanical method. Plant Biosystems, Florence, v. 145, n. sup1, p. 9-18, 2011.

REMPEL, C.; MORÁS, A. P. B.; BICA, J. B.; HERRMANN, M. F. Flora arbórea e arborescente de áreas de preservação permanente em propriedades rurais produtoras de leite no Vale do Taquari, Rio Grande do Sul, Brasil. Pesquisas Botânica, São Leopoldo, n. 71, p.29-45, 2018.

RODRIGUES V, H. P.; LOPES, S. F.; ARAÚJO, G. M. E; SCHIAVINI, I. Composição, estrutura e aspectos ecológicos da floresta ciliar do rio Araguari no Triângulo Mineiro. Hoehnea, São Paulo, v. 37, n. 1, p. 87-105, 2010.

SARAIVA, D. D. Composição e estrutura de uma floresta ribeirinha no sul do Brasil. Biotemas, Florianópolis, v. 24, n. 4, p. 49-58, 2011.

SILVA, A. C.; HIGUCHI, P.; NEGRINI, M.; GRUDTNER, A.; ZECH, D. F. Caracterização fitossociológica e fitogeográfica de um trecho de floresta ciliar em Alfredo Wagner, SC, como subsídio para restauração ecológica. Ciência Florestal, Santa Maria, v. 23, n. 4, p. 579-593, 2013.

STEDILlE, L. I. B.; GOMES, J. P.; COSTA, N. C. F. D.; FERREIRA, P. I.; HIGUCHI, P.; MANTOVANI, A. Vegetative and environmental components in a secondary riparian forest in the Southern Plateau of Santa Catarina, Brazil. Floresta e Ambiente, Seropédica, v. 25, n. 4, p. e20160473, 2018.

TAMBOSI, L. R.; VIDAL, M. M.; FERRAZ, S. F. D. B.; METZGER, J. P. Funções eco-hidrológicas das florestas nativas e o Código Florestal. Estudos avançados, São Paulo, v. 29, n. 84, p. 151-162, 2015.

VOGEL, H. F.; ZAWADZKI, C. H.; METRI, R. Florestas ripárias: importância e principais ameaças. SaBiosRevista de Saúde e Biologia, Campo Mourão, v. 4, n. 1, p. 24-30, 2009.

FLORESTA, Curitiba, PR, v. 51, n. 2, p. 391-399, abril/jun 2021.

Gomes, J. et.al. 